\title{
Participatory assessment of biodiversity conservation in community forestry in Nepal
}

\begin{abstract}
K.P. Acharya ${ }^{1}$, K.R. Goutam ${ }^{2}$, B.K. Acharya ${ }^{3}$ and G. Gautam ${ }^{4}$
The Community Forestry has been the most effective means of managing common forest resources in Nepal. Besides rehabilitating degraded hills, improving environment and contributing to the rural livelihoods, community forestry is claimed to be a major means of biodiversity conservation. It is also argued that the prevalent approach of community forest management threats to the conservation of biodiversity. This paper is based on the findings from two community forest user groups from Central Nepal and argues that the users' innovative practices of active forest management favor biodiversity conservation. The study has documented users' innovations to conserve biodiversity in community managed forests.
\end{abstract}

Key words: Nepal, community forestry, biodiversity conservation and livelihoods

C ommunity forestry programme is regarded as one of the most successful programme in Nepal (Acharya 2003; NPC 2001; Springate-Baginski et al. 1998). However, at the same time many believe that community forest management is protection-oriented where the main forest management activities are limited to the removal of dead, dying trees and leaf litter. As a consequence the users are getting suboptimal benefits (Gilmour and Fisher, 1991; NPC 2001; Shrestha, 2000). In Nepal, the Middle Hills protection area management system is not sufficient to represent the whole ecosystems (HMGN, 2002), and the management approach applied in community forestry should take a balance between biomass production and biodiversity conservation. It has been argued that change in stand composition is possible in community forestry through different management operations (Jackson and Ingles, 1994).

Department of Forest Research and Survey (DFRS) is working to investigate forest management options appropriate to addressing local specific variations related to biodiversity conservation. The conventional research approach is not always appropriate to find solutions of such problems. Realizing this, participatory research approach is increasingly being considered to investigate the problems and find out solutions. In this process, a study to investigate interface between forest and farm biodiversity was initiated in 2004. The aim was to link biophysical and socio-economic variations in biodiversity conservation issues through community forestry and private farm tree management. The first part of the research was conducted in the middle hills region in 2004. This report is the outcome of the second year research conducted in the two community forests in the foothills in the Terai.

The general objective of the research was to contribute for better understanding in biodiversity conservation in the community forestry. The specific objectives were to:

- Assess the existing forest management practices and their effects on plant diversity;

- Identify best practices adopted to conserve plant diversity and

- Investigate the role and capacity of users in promoting biodiversity conservation in community forests.

\section{Biodiversity and community forestry}

The word biodiversity was coined by Prof E.O. Wilson to express total variation of life as a contraction of biological diversity. The components of biodiversity are ecosystem, species and genetic variation. The community forestry is a social process in which user groups share mutually recognized claims to specify their use rights to the management, development and utilization of forest. The issue of

\footnotetext{
${ }^{1}$ Research Officer, Department of Forest Research and Survey, Email-kpacharya1@hotmail.com

${ }^{2}$ Asst. Research Officer, Department of Forest Research and Survey, Email-keshab_gtm@yahoo.com

${ }^{3}$ Ranger, Department of Forest Research and Survey

${ }^{4}$ Ranger, Department of Forest Research and Survey
} 
biodiversity conservation constitutes of different variables in a community forest. Such variables could be forest management objectives, silvicultural practices, forest resource condition, species diversity, nature and kinds of species, forest products and watershed value, habitat conservation, user's confidences, learning behavior and frequent monitoring and evaluation activities.

Recent evidences indicate that Community Forest User Groups (CFUGs) are slowly moving towards active forest management (Neupane, 2000; Khanal, 2002; Malla, 2000; Wagle, 2002). The active forest management approach calls for the implementation of various silvicultural and harvesting activities in the forests (Acharya, 1997; Branney, 1996). Such active forest management by CFUG can lead to an increased supply resulting in increased benefits to users consequently improving the livelihoods of the rural people. The rural people with subsistence agriculture may not put equal value to all plant species growing in their forest and putting equal value to all species may not produce forest products benefits that can be maximized with few selected fast growing and highly demanding species (Acharya, 2003; Rai et al., 2004). Recent study (Acharya, 2006) has shown that ecological indices such as Shannon-Weiner index $\left(\mathrm{H}^{\prime}\right)$ is higher in farm land compared to Community forests. In addition, the applications of various silvicultural and harvesting activities in the forests may affect forest structure and composition consequently losing biodiversity. On the other hand, CFUGs might have been adopting innovative practices (best practices) to address biodiversity conservation, which are unknown to other users or development workers. Hence, there is a gap in understanding users' choice on different forest management operations and their effects on biodiversity conservation.

\section{Material and methodology}

\section{Study sites}

The study was conducted in Nawalpur Saraswoti (Basamadi) Community Forest (CF) and Chakradevi Community Forest in Makawanpur district. These two forests were located in similar geographical and ecological conditions. It was assumed that, the only difference is in forest management practices which have implications on biodiversity conservation. Both of these forests are tropical Sal (Shorea robusta) forests in the foothills of the Terai region. The Nawalpur $\mathrm{CF}$ was known for active $\mathrm{CF}$ and Chakradevi $\mathrm{CF}$ was recognized as passive CF. However, both the forests were under community management since the past

Table 1 : Bio-physical and socio-economic characteristics of the study sites

\begin{tabular}{lll}
\hline \multicolumn{1}{c}{ Characteristics } & \multicolumn{1}{c}{ Nawalpur Saraswoti CFUG } & \multicolumn{1}{c}{ Chakradevi CFUG } \\
\hline Location of forest & Hetaunda munipilicity 11 & Basamadi VDC 5 \\
Aspect & Southern & Southern \\
Topographical region & Inner terai & Inner terai \\
Forest origin & Natural & Natural \\
Forest type & Shorea robusta & Shorea robusta \\
Forest area & 200 ha & 109 ha \\
Forest development stages & Pole & Pole \\
No of Households & 568 & 152 \\
Access to road & Easy & Easy \\
Distance from district head quarter & $3.0 \mathrm{~km}$ & $3.5 \mathrm{~km}$ \\
Duration of community management & 10 years & 9 years \\
\hline
\end{tabular}

Table: 2 : Major lists of activities in the study

\begin{tabular}{|c|c|}
\hline Stages & Activities \\
\hline Selecting CFUGs & $\begin{array}{l}\text { Developing selection criteria, Preparing list of potential CFUGs, Discussion } \\
\text { with district stakeholders and selection of CFUGs }\end{array}$ \\
\hline $\begin{array}{l}\text { Identifying research problem } \\
\text { and designing research plan }\end{array}$ & $\begin{array}{l}\text { Developing a list of issues and problems of selected CFUGs, discussing with } \\
\text { DFO and other stakeholders, prioritizing issues and identifying research } \\
\text { issues, defining roles and responsibilities. }\end{array}$ \\
\hline $\begin{array}{l}\text { Implementing research and } \\
\text { collecting information }\end{array}$ & Conducting research, developing recording system \\
\hline Results and Extension & $\begin{array}{l}\text { Analyzing and interpreting results, deriving conclusions, organizing workshop } \\
\text { and disseminating results. }\end{array}$ \\
\hline
\end{tabular}


9-10 years. The field work was conducted during June 2005. Some of the key features of two CFUGs are presented in Table 1.

\section{Methodological approach}

The following methodologies were used to gather information in the study.

\section{Questionnaire Survey}

Semi-structured questionnaire survey was conducted among the users of the forests. The questionnaire was about the forest management and silvicultural activities, species preference and selection criteria, importance of biodiversity and demand and supply situation of the forest products.

\section{Social and Resource Mapping}

Participatory social and resource maps were prepared to collect the information on the distribution and condition of forest resources. It was also useful to obtain the perception of nearby and distant users towards forest management issues.

\section{Focus Group Discussion}

Focus group discussion was conducted to obtain the information on forest management and silvicultural activities carried out in the forests, species selection criteria and preferences, varying perceptions towards management and biodiversity conservation issues. The discussions were concentrated mainly in the male, female and ethnic groups and groups of closest and distant users.

\section{Key Informants Survey}

A survey was conducted with the key informants like teachers and users' group committee executives to collect the information on the forest management and biodiversity conservation practices, species preference and nature and status of forest resources in the forests.

\section{Species Ranking}

Species preference ranking was carried out on the basis of different criteria made by the users. Likewise pair wise ranking of most preferred 15 species was done. Ranking was done in different interest groups of the users. The method was very useful to identify species selection criteria and most preferred species in the community forests.

\section{Users' Mass Meeting}

Detailed discussion was done in users' mass meeting to triangulate the information found from different sources. The additional information on the forest products, management and silvicultural activities and biodiversity conservation issues were obtained from this discussion.

\section{Stakeholders' workshop}

A workshop with participation of all the stakeholders was organized. Chairperson and other active members, men and women, of the two CFUGs, District Forest Offices staff, Biodiversity Sector Programme for the Terai and Siwaliks (BISEP-ST) staff and other stakeholders had participated in the workshop and shared their views on the forest management and biodiversity conservation in community forestry. The workshop was useful to identify roles and responsibilities of different stakeholders in biodiversity conservation in community forests.

\section{Forest Resources Inventory}

Forest resources inventory, as per the inventory guidelines, was carried out in both of the forests. The inventory was carried out with $0.5 \%$ sampling intensity. The Diametre at Breast Height (DBH) of trees of and above pole stage was measured while the number counted for all others i.e. seedlings and saplings, herbs, shrubs, grasses and climbers.

\section{Review of OP and constitution and other literatures}

Operational plans and constitutions of the CFUGs and published and unpublished literatures related to the study were reviewed mainly from the District Forest Office (DFO), Makawanpur.

\section{Limitations}

The study was limited to the plant diversity in the community forests. As baseline information was lacking, users recalling was used as one of the most important data source.

\section{Results and discussions}

\section{Profiles of local stakeholders}

The CFUGs are executive agencies for the management of community forests. The technical advice is being provided by the DFO located at the 
district headquarter and territorial offices. In addition, the support staff were overloaded with increasing workload due to the expansion of the programme. Civil society organizations such as NGOs, federations of forest users groups were increasingly acting as service providers to the CFUGs. The DFRS was responsible to execute this research in collaboration with the stakeholders.

\section{Participation in field research}

The identification of objectives and the research issue was not participatory at users' level. However, the agenda were discussed with all the stakeholders and a set of process was followed at various levels. There were several interactions at the beginning in the district level, before finalizing the CFUGs to be studied. Table 2 illustrates how the process was followed and kinds of activities were performed.

There was an active participation from different stakeholders including women groups. The preliminary analysis and initial outcomes of the field were shared among the stakeholders.

\section{Forest management operations}

Forest scientists have defined forest management as the application of the knowledge, which has been acquired in all branches of forestry and the allied sciences to the management of forests in the interest of man (Jerram, 1983) where silviculture is a component. Silviculture includes a range of activities and operations to the forest. However, the CFUGs understand two silvicultural activities namely "Godmel" and "Jhadi safai" as substitute of forest management. The terms "Godmel and Jhadi safai" mean removal of shrubs, climbers and low quality timber species (Kukath) to create favorable environment for the desired species. It can be inferred that present forest management strategy is directed towards the production of medium term to longterm products, mainly wood products. The nature of understanding on forest management was found to be similar to earlier study by Acharya et al. 2004 . However, users were also aware of the fact that every living being on the earth has rights to survive.

The CFUGs were predominantly applying selective felling, singling, thinning, pruning, lopping, and weeding/cleaning operations followed by plantations, soil conservation work and leaf litter collection. These forest management operations were carried out depending upon the nature, kind and conditions of the forests. The application of such activities may promote uniformity in species composition, spacing and canopy development.

The Nawalpur Forest was handed over as CF in 1996. The forest was divided into 5 blocks. Forest management activities like removal of dead and fallen trees, shrub and climber cutting (particularly thorny species and Eupatorium), thinning, pruning, singling and plantation were carried out each year.

The Chakradevi Forest was handed over in 1997. to the local communities. The whole forest was divided into five blocks. One block was designed to be treated each year applying forest management activities including shrub and climber cutting (Jhadi safai), pruning and singling and plantation as required. However, the main forest management practice adopted was the removal of dead and fallen trees which was recognized as passive forest management.

\section{Number and nature of species}

Both the community forests were dominated by Sal (Shorea robusta). A total of 160 plant species were recorded in the two CFs (Annex 1). A total of 55 tree species were found in the study area, out of which one half (28 species) were common to both of the CFUGs. However, the number of species of all plant life forms was higher in actively managed forest (47 trees and 67 others in Nawalpur Saraswoti compared to 36 trees and 65 other species in Chakradevi). However, unlike tree species, the number of common species of plants other than trees in both the CFs was less. Out of total 105 species, only $38\left(1 / 3^{\text {rd }}\right)$ were common to both the CFs indicating great variation and sensitivity in their existence in two CFs, actively managed and poorly managed.

\section{Species diversity, richness and dynamics}

A total of 55 tree and 105 other species were recorded in the two community forests. Table $3 \mathrm{a}$ indicates that higher number of plant species was associated with the actively managed forest. The diversity indices of trees in two CFs are not varied significantly (Table 3a). However, the richness index of tree species is higher in Nawalpur CF than Chakrdevi CF. Higher richness index refers to the higher number of species and the higher number of individuals within the species regardless of evenness in distribution. The richness index was found higher in actively managed 
forest in previous study which is the case in the present study also. The data presented in Table $3 \mathrm{c}$ are not supported by previous study (Acharya et al. 2004). The previous study resulted in higher relative density of the most dominant species in actively managed forests where as in this case it was observed in passively managed forests. This is also supported by Table 3b. However, Diversity Index $\left(\mathrm{H}^{\prime}\right)$ is dependent on the distribution of species and their evenness. It is higher in uniformly distributed forest than that with uneven distribution. The higher $\mathrm{H}^{\prime}$ in Nawalpur indicates higher uniformity than in Chakradevi CF where fewer species have higher dominance over others resulting in lower $\mathrm{H}$ '. There is a need to relate with other several factors such as level of disturbances and response of the species which is not known. In addition, the lack of baseline data limits the conclusive remarks.

Table $3 \mathrm{~b}$ shows the distribution of various development stages of various life forms in the community forests. The higher number of trees was observed in passively managed forest providing evidences of limited harvesting than in actively managed forests. Similarly, Table $3 \mathrm{c}$ indicates higher relative density of Sal species in passively managed forest. It indicated that harvesting operations may create room for various species others than the dominant species.

\section{Selective approach and biodiversity conservation}

The CFUGs have developed some criteria to determine the species to be retained or to be removed during the silvicultural operations. The main criteria to retain are the usefulness of the species to fulfill their forest product needs. The criteria to remove a species are shrub, thorny species, dead, dying and damaged individuals of all species, species and individuals competing with main crop and low quality timber species. It obviously leads to selective approach for the species. The users want to retain species that give direct benefits. Multipurpose tree species have higher chances for promotion. The main species preferences criteria in the two CFs (Priority wise) were:

1. Timber

2. Specific use (eg. Sandan has specific use for making plough)

3. Firewood

4. Medicinal use

5. Others (Fodder, Fruits etc.)

The preferences criteria has resulted in the species preferences list as in Table 4.

Users placed Sal (Shorea robusta) in the top indicating the most preferred species. The users do not prefer low quality timber, shrub and climber species and many of the grasses and herbs. Banmara (Eupatorium adenophorum), Titepati (Artemesia vulgaris), Unnue (Gleichenia species), Damaru (Maclura cocbinchinensis) and Maidal (Randia dumetorum) are some of the species, which have no direct use values. In both the community forests, low quality timber and almost all shrubby species were regarded as unwanted species and the management activities were focused towards removing them in favor of Sal. It may lead to monoculture of Sal species. It will have negative

Table 3a: Diversity and richness indexes of two community forests

\begin{tabular}{lrrrrrrr}
\hline \multirow{2}{*}{ Forest } & \multicolumn{2}{c}{ No. of species } & \multicolumn{2}{c}{ Shannon-Weiner index(H') } & \multicolumn{2}{c}{ Richness Index (RI) } \\
\cline { 2 - 8 } & \multicolumn{2}{c}{ Tree } & Others* & \multicolumn{1}{c}{ Tree } & Others* & \multicolumn{1}{c}{ Tree } & Others* \\
\hline Nawalpur Saraswoti CF & 47 & 67 & 1.01 & 3.22 & 3.96 & 5.54 \\
Chakradevi CF & 36 & 65 & 1.28 & 3.41 & 3.04 & 5.26 \\
\hline
\end{tabular}

*Others include shrubs, herbs and grasses

Table 3b: Density of various life forms in two community forests (No/ha)

\begin{tabular}{lrrrrr}
\hline \multicolumn{1}{c}{ Forest } & \multicolumn{1}{c}{ Regeneration } & \multicolumn{1}{c}{ Sapling } & \multicolumn{1}{c}{ Poles } & \multicolumn{1}{c}{ Trees } & \multicolumn{1}{c}{ Total } \\
\hline Nawalpur Saraswoti CF & $1,08,164$ & 3,127 & 464 & 85 & $1,11,841$ \\
Chakradevi CF & 95,655 & 3,393 & 571 & 100 & 99,719 \\
\hline
\end{tabular}

Table 3c: Density of most dominant species in two community forests

\begin{tabular}{lrrrrrr}
\hline \multirow{2}{*}{ Forest } & \multicolumn{3}{c}{ Density (No/ha) } & \multicolumn{2}{c}{ Relative Density \% } \\
\cline { 2 - 7 } & Sal regn & $\begin{array}{c}\text { Total } \\
\text { regn }\end{array}$ & $\begin{array}{c}\text { Sal, above } \\
\text { regn. }\end{array}$ & $\begin{array}{c}\text { Total, } \\
\text { above regn }\end{array}$ & Sal regn & $\begin{array}{c}\text { Sal, above } \\
\text { regn }\end{array}$ \\
\hline Nawalpur Saraswoti CF & 89,693 & $1,08,164$ & 2,097 & 3,676 & 82.9 & 57.0 \\
Chakradevi CF & 71,884 & 95,655 & 2,859 & 4,064 & 75.1 & 70.3 \\
\hline
\end{tabular}


Table 4: Most preferred species in the study area

\begin{tabular}{ll}
\hline Preferred species (Priority wise) & Main uses \\
Sal (Shorea robusta) & Timber, firewood \\
Sandan (Oogenia Oogenesis) & Agricultural implement, Timber \\
Chanp (Michelia champaca) & Timber \\
Saj (Terminalia tomentosa) and Karma (Adina cardifolia) & Timber, firewood \\
Chilaune (Schima wallichi) & Firewood \\
\hline
\end{tabular}

implications for biodiversity conservation through community forestry.

The strategy to select species only to maximize wood production having no priority for biodiversity conservation contradicts with earlier studies of Ingles and Jackson (1994) and Dahal (1994). They claimed that CFUGs are more effective in forest management with higher number of species due to the opportunity to obtain wide variety of products. It would be more logical to point out that CFUGs are more effective to manage with higher number of "useful" species. Aus der Beek et al 1997 claimed that there are specific clauses included in Operational Plan (OP) of the CFUGs to conserve biodiversity and provided examples from 5 CFUGs from Dolkha, however all these conservation efforts are directed to conserve high value tree species such as Quercus spp.

\section{Implications of active forest management on biodiversity}

In the early phase, while the major objective of the CF was forest protection, CF undoubtedly contributed for biodiversity conservation. But now, the users are implementing active forest management strategy in the forests towards producing good quality timber. The two silvicultural activities namely "Godmel" and "Thadi safai" are understood as substitute of forest management. The users have adopted silvicultural activities, as an opportunity to remove all unwanted species from the forest, which of course could be essential to enhance preferred wood productivity. The main targeted plants are shrubs and low quality timber species (Kukath). The "Godmel" may cause altered diversity of tree species and modified forest structure and composition. The "Jhadi katne" may lead to the conversion of shrub land forests to high forest. However, the active management can be utilized as an opportunity to conserve biodiversity where there is possibility of establishing new species other than the dominant resulting in higher diversity. Sustainable biodiversity utilization will promote biodiversity conservation in $\mathrm{CF}$.

\section{Best practices and constraints to biodiversity conservation}

The study revealed that CFUGs are increasingly adopting measures for biodiversity conservation in the CF. Few major initiatives observed particularly in Nawalpur CF were:

- Allocation of biodiversity conservation area

- Shifting tree selection criteria during thinning from species to tree condition.

- Initiatives to maintain all the plant species during management operations based on the condition of individual plant.

- Species conservation

The biodiversity conservation was constrained by few basic problems. The research has identified following points that can be considered as constraints for biodiversity conservation.

- Inconsistent understanding of biodiversity conservation

- Poor know-how on biodiversity conservation and its importance

- Problem in identification of medicinal herbs and other NTFPs

- Basic needs priority over conservation

\section{Roles of different stakeholders}

The CFUGs, service providers and the government's roles to implement biodiversity conservation initiatives in CF is presented in the Table 5.

\section{Conclusions}

Active management practices have influences on structure and composition of forests. Density of Sal is gradually increasing in the expense of low timber and shrub species. This may lead to single species dominated forest and loss of diversity of many plant and animal species. Human induced and rapid conversion of forest structure through species preference and silvicultural operations harms natural environment, ecological processes and biological 
Table 5: Roles and responsibilities of CFUGs and the government to support biodiversity conservation in $\mathbf{C F}$

\begin{tabular}{ll}
\hline \multicolumn{1}{c}{ CFUGs } & \multicolumn{1}{c}{ Government } \\
\hline Bio-friendly utilization of the forest & $\begin{array}{l}\text { Develop clear policy and guidelines related to } \\
\text { biodiversity conservation in CF } \\
\text { Implementation of appropriate extension media to make } \\
\text { aware all the users }\end{array}$ \\
Awareness creating in the CFUGs & $\begin{array}{l}\text { Frequent interaction and training to users about the } \\
\text { recent developments/approaches }\end{array}$ \\
$\begin{array}{l}\text { Implementing knowledge acquired through different } \\
\text { training/workshops }\end{array}$ & $\begin{array}{l}\text { Dissemination of knowledge to users on the importance } \\
\text { adoption of appropriate forest management activities } \\
\text { such as controlled grazing and appropriate harvesting } \\
\text { Fire control }\end{array}$ \\
Effective M\&E system & $\begin{array}{l}\text { adopting reward and punishment system } \\
\text { Effective M\&E system }\end{array}$ \\
\hline
\end{tabular}

diversity. Such situation will lead to the creation of modified forest types and ecosystems ultimately effecting ecological functions and services of forests. There are at least three different types of changes taking places in terms of forest structure and composition. Firstly, the forest types are slowly converting from mixed (Sal Mixed) to monoculture (Sal). Secondly, the shrub and tree diversity may gradually decrease. Lastly, the most critical threat is for the shrub species such as climber and thorny species. It suggests that shrub land areas are gradually converting to high forest and shrub land species are gradually disappearing.

The active management does not always lead to species reduction; it depends on the kinds of activities undertaken and specific procedures adopted. The CFUGs have demonstrated innovative approaches to address biodiversity conservation. These are indications that users are able to address these concerns through proper attention by the service providers. However, there is a need to scale up these activities through awareness and by creating favorable environment. In the past, the conservation of biodiversity has been mostly understood in terms of the management of protected areas and natural forests, ignoring the possible role of community managed forests. This traditional view is especially inadequate for the community forestry.

The adoption of approach maintaining species other than Sal during thinning operations, maintaining undergrowth in a forest with sapling and above development stages and retaining of undisturbed area along river side, stream slopes will help conserve biodiversity in $\mathrm{CF}$.

Placing proper attention in the community forestry management process and practices can minimize the conservation threats to biodiversity outside protected areas particularly for shrubs and tree species. The activities related to the awareness creation about the importance of biodiversity at user group level, updating baseline information on biodiversity issues addressing current status, trends and threats, identification of threatened species and their distribution study and biodiversity recording and registration at local level are some of the key areas where immediate action is necessary. Few initiatives adopted by the CFUGs to address the biodiversity issues are to be scaled up. Sustainable utilization of biodiversity through the development of biodiversity based enterprises can be supposed to be beneficial for participatory biodiversity conservation.

\section{References}

Acharya, K.P. 2006. Linking trees on farms with biodiversity conservation in subsistence farming systems in Nepal. Biodiversity and Conservation 15:631-46.

Acharya, K.P., Goutam, K.R. and Acharya, B. 2004. The Impacts of Forest Management in Community Forestry on Biodiversity : A Case Study from Midhills. Forest Research Leaflet no. 18. Department of Forest Research and Survey, Kathmandu, Nepal.

Acharya, K.P. 2003. Sustainability of support for community forestry in Nepal. Forest, Trees and Livelihoods, 13(3): 247-260.

Acharya, K.P. 1997. The Management of Common Forest Resources: An Evaluation of Bharkhore Forest User Group, Western Nepal. M.Sc. thesis, The University of Edinburgh, Scotland, UK.

Aus der Beek R., Rai, C., and Schuler, K. 1997. Community Forestry and Biodiversity: Experiences from Dolkha and Ramechhap districts, Nepal. Paper presented at the seminar 
on "Conserving biodiversity in Nepal's community forestry" Organised by the Department of Forest and Nepal Biodiversity Action Plan, $2^{\text {nd }}$ October, 1997 Kathmandu, Nepal.

Branney, P. 1996. The New Silviculture: India and Nepal. In Participatory Forestry: The Process of Change in India and Nepal. (ed) Hobley, M. ODI, London 190-210, pp.

Dahal, D.R. 1994. A review of Forest User Groups: Case studies from Eastern Nepal, ICIMOD, Kathmandu, Nepal.

Gilmour, D.A. and Fisher, R.J. 1991. Villagers, Forest and Foresters: The Philosophy, Process and Practice of Community Forestry in Nepal, Sahayogi Press Kathmandu. 212 pp.

HMGN. 2002. Nepal Biodiversity Strategy, Ministry of Forests and Soil Conservation, Kathmandu, Nepal.

Jackson, W.J. and A.W. Ingles 1994. Developing Rural Communities and conserving the biodiversity of Nepal's Forests Through Community Forestry. Paper presented at a seminar on community development and conservation of forest biodiversity through community forestry: Bangkok, Thailand, 26-28 October 1994.

Jerram, M.R.K. 1983. A text-book on Forest Management. International Book Distributors, Dehradun, India (reprint) 156 pp.
Khanal, K.P. 2002. Under utilisation in community forestry: a case study from Lalitpur district. Banko Janakari 12(2): 26-32.

Malla, Y.B. 2000. Impacts of community forestry policy in rural livelihoods and food security in Nepal. Unasylva 200: 38-45.

Neupane, H.R. 2000. Factors that influence poorer households access to forest products from community forests: An analysis of decisionmaking and benefit sharing process. A thesis submitted for M. Phil. degree at the University of Reading, UK.

NPC. 2001. Mid-term Evaluation of the Ninth Five Year Plan, National Planning Commission, Kathmandu, Nepal.

Shrestha, K. 2000. Protection versus active management, of community forests. Proceeding of the Workshop of Community Based Forest Resource Management, Godawari, Lalitpur 20-22 November Joint Technical Review Committee, MOFSC.

Springate-Baginski, O., Soussan J., Dev O.P., Yadav N.P. and Kiff, E. 1998. Community Forestry in Nepal: Sustainability and impacts on common and private property resource management, report on first phase of field research, Environmental Centre, Leeds University/NRI/NUKCFP.

Wagle, S. 2002. Contribution of community forestry to the livelihood of local participants in the middle hills of Nepal: A case study of Makawanpur district, An M. Sc thesis submitted to the Asian Institute of Technology, Bangkok, Thailand. 


\section{Annex 1: List of species found in the study area}

1. Nawalpur Sarswoti CF

\begin{tabular}{|c|c|c|c|c|c|}
\hline \multicolumn{3}{|c|}{ Tree species } & \multicolumn{3}{|c|}{ Herbs/shrubs/climbers/grass } \\
\hline SN & & Species & $\mathbf{S N}$ & & Species \\
\hline 1 & Amala & Emblica officinalis & 1 & Amiloghans & Embelia nagushia \\
\hline 2 & Amaro & Antidesma diandrum & 2 & Archal & \\
\hline 3 & Amba & Psidium guajava & 3 & Arerikanda & Caesalpinia decapetela \\
\hline 4 & Ankhatarua & Trichilia connaroides & 4 & Ausadhi & \\
\hline 5 & Archal & & 5 & Balujhar & \\
\hline 6 & Asarekaingyo & & 6 & Banbesar & \\
\hline 7 & Badkaule & & 7 & Banmara & Eupatorium odoratum \\
\hline 8 & Bahunikath & Hydrangea anomala & 8 & Bansimilahara & Ceropegia pubescens \\
\hline 9 & Barro & Terminalia chebula & 9 & Batulpatelahara & $\begin{array}{l}\text { Stephania elegans, Cissampele } \\
\text { pareira }\end{array}$ \\
\hline 10 & Bhalayo & Rhus succedanea & 10 & Betlauri & \\
\hline 11 & Bhille & & 11 & Bhakauli & \\
\hline 12 & Botdhangero & Lagerstroemia parviflora & 12 & Bhati & Clerondendron infortunatun \\
\hline 13 & Chilaune & Schima wallichi & 13 & Bhatmaseghans & \\
\hline 14 & Chiuri & Madbuca butyracea & 14 & Bhatteghans & \\
\hline 15 & Dadukuchche & & 15 & Bhorla & Baubinia vablii \\
\hline 16 & Gidarikanda & Premna integrifolia & 16 & Bhyakurlahara & Dioscorea deltoidea \\
\hline 17 & Harro & Terminalia bellarica & 17 & Bokejamuno & \\
\hline 18 & Jalme & & 18 & Chitrebanso & Arthraxon lancifolius \\
\hline 19 & Jamuno & Syzygium cumini & 19 & Chultheghans & \\
\hline 20 & Kaijal & Bischofia javanica & 20 & Datiwan & Achyranthes bidentata \\
\hline 21 & Kaingyo & Grevillea robusta & 21 & Dhairo & Woodfordia fruticosa \\
\hline 22 & Kalikath & Myrsine semiserrata & 22 & Dhotipateghans & \\
\hline 23 & Karma & Adina cordifolia & 23 & Dhupi-jhar & \\
\hline 24 & Khirro & Sapium insigne & 24 & Dubo & Cynodon dactylon \\
\hline 25 & Kumbhi & Cocbliospermum religiosa & 25 & Gaikhure & \\
\hline 26 & Kutmiro & Litsea monopetala & 26 & Gaitihareghans & Inula cappa \\
\hline 27 & Kyamuno & Syzygium cerasoides & 27 & Galeni & Leea robusta \\
\hline 28 & Latikath & Cornus oblonga & 28 & Ghantelahara & \\
\hline 29 & Masala & Eucalyptus spp & 29 & Ghodedubo & \\
\hline 30 & Mauwa & Engelhardtia spicata & 30 & Ghodeghans & \\
\hline 31 & Paderi & Stereospermum spp & 31 & Githalahara & Dioscorea bulbifera \\
\hline 32 & Phalamekath & & 32 & Gobrelahara & \\
\hline 33 & Pharim & & 33 & Hatkatuwaghans & \\
\hline 34 & Phirphire & Acer oblongum & 34 & Kagchuchelahara & \\
\hline 35 & Piyari & & 35 & Kali Niuro & \\
\hline 36 & Putalikath & & 36 & Kalilahara & \\
\hline 37 & Rajbrikshya & Cassia fistula & 37 & Kalisinke & \\
\hline 38 & Rato kaidal & & 38 & Kanchirno & \\
\hline 39 & Ritha & Sapindus mukorossi & 39 & Kapaseghans & \\
\hline 40 & Rudilo & Pogostemon glaber & 40 & Kukurdainolahara & Smilax menispermoides \\
\hline 41 & Sadan & Ougeinia dalbergiodes & 41 & Kurilo & Asparagus racemosus \\
\hline 42 & Saj & Terminalia tomentosa & 42 & Kuroghans & Cyathula capitata \\
\hline 43 & Sal & Shorea robusta & 43 & Kuthurke Niuro & \\
\hline 44 & Setosiris & Albizia procera & 44 & Lajjawati & Mimosa pudica \\
\hline 45 & Sindure & Mallotus philippenenis & 45 & Madanelahara & \\
\hline 46 & Tantari & Dillenia pentagyna & 46 & Maidalkanda & Randia dumetorum \\
\hline 47 & Unknown 1 & & 47 & Musekharu & \\
\hline & & & 48 & Nagbeli & Lycopodium clavatum \\
\hline & & & 49 & Niuro & \\
\hline & & & 50 & Panilahara & Vitis repanda \\
\hline & & & 51 & Panisaro & Nephrolepis cordifolia \\
\hline
\end{tabular}




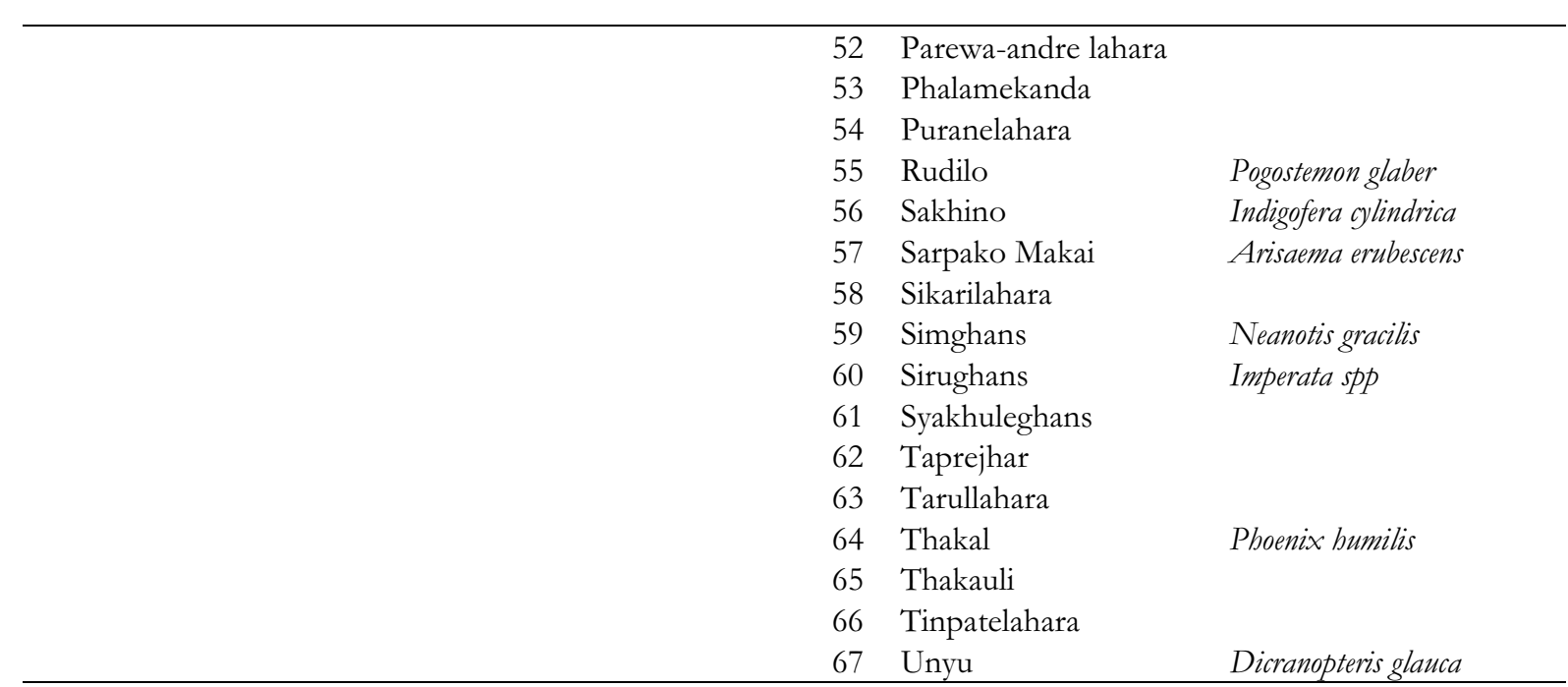

\section{Chakradevi CF}

\begin{tabular}{|c|c|c|c|c|c|}
\hline \multicolumn{3}{|c|}{ Tree species } & \multicolumn{3}{|c|}{ Herbs/shrubs/climbers/grass } \\
\hline SN & & Species & SN & & Species \\
\hline 1 & Amala & Emblica officinalis & 1 & Achirnoghans & \\
\hline 2 & Amaro & Antidesma diandrum & 2 & Akhleghans & Chirita urticaefolia \\
\hline 3 & Archal & & 3 & Amppate & \\
\hline 4 & Asare & Lagerstroemia parviflora & 4 & Ararighans & \\
\hline 5 & Badkaule & & 5 & Arerikanda & Caesalpinia decapetela \\
\hline 6 & Bahunikath & Hydrangea anomala & 6 & Balujhar & \\
\hline 7 & Barro & Terminalia chebula & 7 & Banbesar & \\
\hline 8 & Bel & Angele marmelos & 8 & Bankapas & Thespesia lampus \\
\hline 9 & Bhalayo & Rhus succedanea & 9 & Bankarkalo & \\
\hline 10 & Botdhangero & Lagestroemia parviflora & 10 & Banmara & Eupatorium odoratum \\
\hline 11 & Chilaune & Schima walichii & 11 & Bansimilahara & Ceropegia pubescens \\
\hline 12 & Dadukuche & & 12 & Batulpatelahara & \\
\hline 13 & Damaiphalrukh & & 13 & Bhati & Clerondendron infortunatun \\
\hline 14 & Gindari & Premna longofolia & 14 & Bhatteghans & \\
\hline 15 & Harchur & Viscum articulatum & 15 & Bhorla & Baubinia vablii \\
\hline 16 & Harro & Terminalia bellarica & 16 & Bhyagutokolahara & \\
\hline 17 & Jalme & & 17 & Bhyakurlahara & Dioscorea deltoidea \\
\hline 18 & Jamuno & Syzigium cumini & 18 & Bokejamuno & \\
\hline 19 & Jogikath & & 19 & Charcharelahara & \\
\hline 20 & Kaingyo & Grevillea robusta & 20 & Chitrebanso & Arthraxon lancifolius \\
\hline 21 & Kandejamuno & & 21 & Chultheghans & \\
\hline 22 & Karma & Adina cordifolia & 22 & Dhairo & Woodfordia fruticosa \\
\hline 23 & Kumbhi & Cochliospermum religiosa & 23 & Dhotipateghans & \\
\hline 24 & Kutmiro & Litsea monopetala & 24 & Dubo & Cynodon dactylon \\
\hline 25 & Kyamuno & Syzygium cerasoides & 25 & Dudheghans & \\
\hline 26 & Latikath & Cornus oblonga & 26 & Dudhelahara & Trachelospermum lucidum \\
\hline 27 & Odal & Sterculia villosa & 27 & Gahatelahara & \\
\hline 28 & Pandari & Stereospermum spp & 28 & Galeni & \\
\hline 29 & Piyari & & 29 & Gaujo & \\
\hline 30 & Putalikath & & 30 & Ghatejhar & \\
\hline 31 & Rajbrikshya & Cassia fistula & 31 & Githalahara & \\
\hline 32 & Sadan & Ongeinia dalbergiodes & 32 & Gobrelahara & \\
\hline 33 & Saj & Terminalia tomentosa & 33 & Golkakri & \\
\hline 34 & Sal & Shorea robusta & 34 & Hatkatuwahans & \\
\hline 35 & Seto Siris & Albizia procera & 35 & Jhumjhumlahara & \\
\hline
\end{tabular}




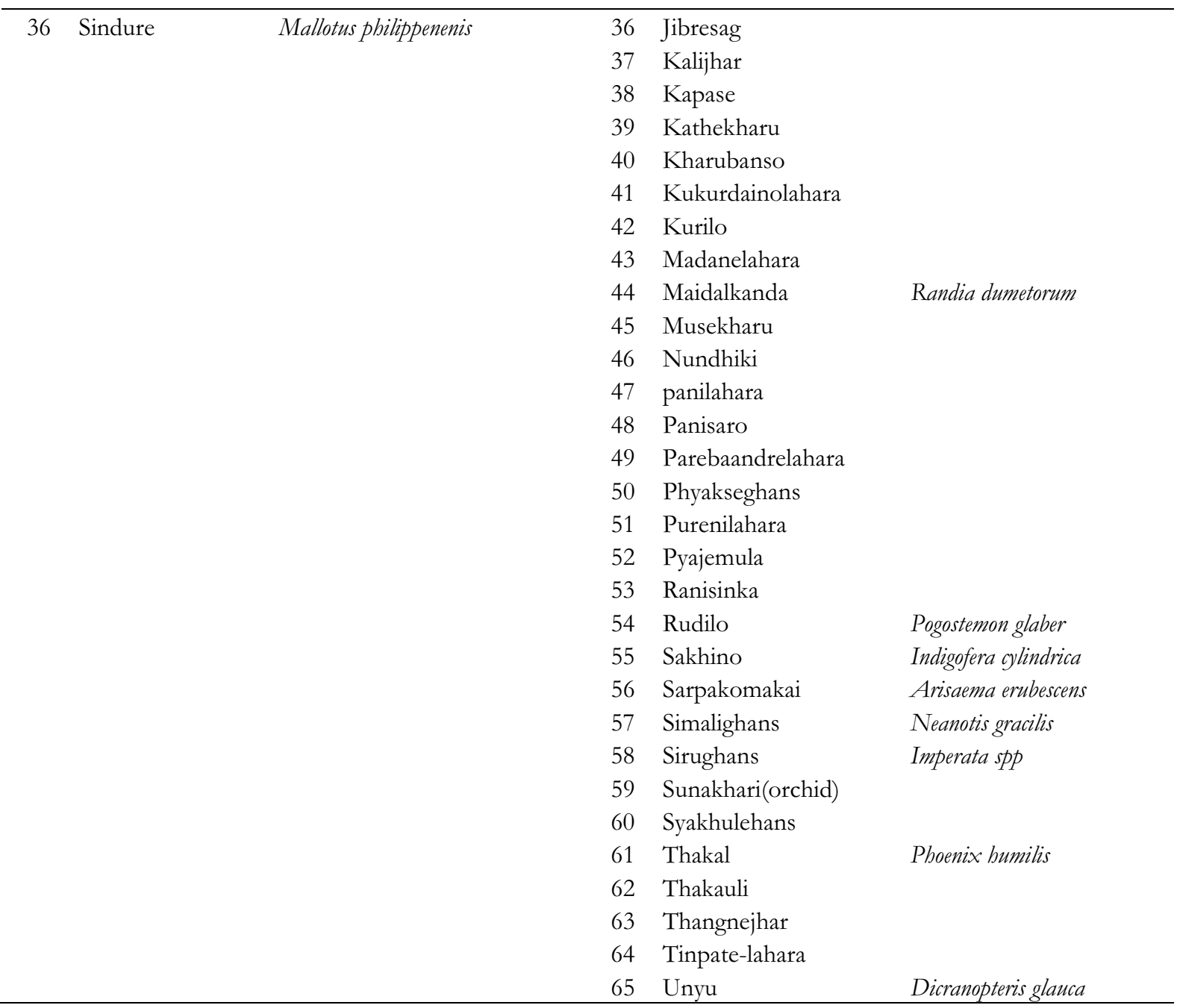

